\title{
Address to the geographical section of the British association, 1901
}

\author{
Hugh Robert Mill D.Sc., LL.D., F.R.S.E., F.R.G.S., President of the Section
}

To cite this article: Hugh Robert Mill D.Sc., LL.D., F.R.S.E., F.R.G.S., President of the Section (1901) Address to the geographical section of the British association, 1901, Scottish Geographical Magazine, 17:10, 505-526, DOI: 10.1080/00369220108733286

To link to this article: http://dx.doi.org/10.1080/00369220108733286

Published online: 27 Feb 2008.

Submit your article to this journal $\pi$

Џlll Article views: 7 


\title{
THE SCOTTISH
}

\section{GE O G R A P H I C L}

\section{MAGAZINE.}

\section{ADDRESS TO THE GEOGRAPHICAL SECTION OF THE BRITISH ASSOCIATION, 1901.}

\author{
By Hugh Robert Mill, D.Sc., LL.D., F.R.S.E., F.R.G.S., \\ President of the Section.
}

\section{On Research in Geographical Science.}

Introductory.-The annual reassembling of friends and fellow-workers in the old revisited towns, and the annual accession of new lovers of science, $\supseteq$ furnish an unique opportunity for a survey of the advances made in each zdepartment, a fitting occasion also for remembering those who have finished their work and can aid our deliberations only by the memory of their example.

Apart from our more intimate losses in the death of many distinguished geographers and devoted workers, the period since our last meeting has been for all a year of mourning. The passing of the nineteenth century was almost like the death of a friend, and it is still difficult to realise that the century which we had been so long in the habit of associating with everything new and great and progressive has itself become part of the past. Few coincidences have been more striking than the almost simultaneous close of that unparalleled reign which gave a name to the Era including all that was best and most characteristic of the century. The death of Queen Victoria carried so keen a sense of personal loss into every heart that few attempts have been made to show how vast a portion of the stream of time-measured by progress -intervened between the terminal dates of her life. Think for a moment of the splendid advances in the one small department of geographical exploration during the late Queen's reign, the multitude of landmarks which have been crowned by the great name of Victoria- of the earth's most southerly land and its most VOL. XVII. 
northerly sea, of the largest lake and most majestic waterfall of Africa, the loftiest lake of Asia, the highest peak in New Guinea, the widest desert and most populous colony in Australia, and of the two thriving seaports on either side of the North Pacific which couple together the British Dominions of western America and eastern Asia.

What could be more appropriate in this first meeting after the close of such a century and of such a reign than to pass in brief but appreciative review the advances of geography during those hundred or those sixtyfive years? One thing in my opinion is more appropriate than to dwell on past triumphs or to regret past greatness, and that is to survey our present position and look ahead. In the first year of a new century and of a new reign we are reminded that we have a future to face and that the world is before us, and I propose to seize this opportunity in order to speak of the science of geography as it is now understood, and especially to urge the importance of the more systematic pursuit of geographical research henceforward.

Geography in the Universities.-The prospect of immediate expansion in many British universities seems at last likely to afford more than one opportunity of wiping out the old disgrace of the neglect of geographical science in the accredited seats of learning. Already Oxford has a wellmanned School of Geography, and Cambridge has a Reader in Geography. The reconstituted University of London occupies the best position in the world for creating a chair of geographical research, situated as it is in the very centre of the comings and goings of all mankind, and in touch with the most complete geographical library and map collection in existence. The new University of Birmingham may, it is hoped, prove better than its promises, and may perhaps after all provide some more adequate treatment of geography than its proposed partition amongst the professors of half a dozen special subjects, all of them concerned in geography, it is true, but none of them individually, nor all of them collectively, capable of embodying that co-ordination of parts into an harmonious unity which gives to geography its power as a mental discipline and its value for practical application. But England in all that pertains to higher education is still a poor country, and the will to do well is hampered by the grinning demon of poverty. Here, on the other side of the Border, we are in a different atmosphere. The wave of the magician's wand in the hands of Andrew Carnegie has brought wealth that last year would have been deemed fabulous to the ancient universities in Scotland, and it will be a disgrace to our country if this splendid generosity does not result in the establishment of one or more fully endowed and completely equipped chairs of geography.

There may still be some people who view geography as the concern only of soldiers and sailors, adventurous travellers, and perhaps of elementary teachers. Exploration is undoubtedly the first duty of geographers, but it is a duty which has been well done, the nineteenth century having left us only one problem of the first magnitude. This is the exploration of the Polar regions, and even here the twentieth century clamours for new methods. 
The Antarctic Expeditions.-This year has seen the long-hoped-for Antarctic expeditions set out on their great quest, a quest. not only of new lands in the southern ice-world, but of scientific information regarding all the conditions of the vast unknown region. Two expeditions have been planned in Great Britain and Germany with a complete interchange of information regarding equipment and methods of work. Provision has been made for simultaneous magnetic and meteorological observations, and in some instances for the use of instruments of identical construction, and all possibility of any unseemly rivalry.in striving for the childish distinction of getting farthest south has been obviated by the friendly understanding that the British ship shall explore the already fairly known Ross quadrant, where it is pretty sure that extensive and accessible land will favour exploration by sledges, while the Germans have chosen the entirely unknown area of the Enderby quadrant which no ice-protected steamer has yet attempted to penetrate, and where they enter a region of potential discovery before they cross the Antarctic circle.

The British Expedition is equipped on the good old plan that produced such fine results in the days of Cook and Ross; it is manned by sailors of the Royal Navy and is under the command of a gallant naval officer, though, unlike the earlier vessels, the Discovery is not herself a naval ship. As in the days of Cook the naval officers are assisted in their non-professional work by several young and promising scientific men, two of whom have already had experience of work in the Polar regions. These have the great advantage of the counsel and help of Mr. George Murray of the British Museum, who goes as far as Melbourne in the position of Director of the Scientific Staff.

No one who has seen the zeal and unflagging enthusiasm with which Sir Clements Markham has organised the expedition can hesitate to accord to him in fullest measure the credit for its successful inauguration. And no one who has seen the quiet and good-humoured determination of the commander, Captain R. F. Scott, in overcoming many irritating preliminary difficulties, can doubt his fitness to undertake the heavy responsibilities of the voyage. I at least am sure that he will be a worthy successor to Cook, Ross, Franklin, Nares, and all the other officers who have made their names and the name of the British Navy famous in Polar service. The second in command, Lieutenant Armitage, R.N.R., has had several years of Arctic experience, and among the crew there are some old whalers whose knowledge of the ways of sea-ice should prove of value. The ship and her equipment are unique; it is no exaggeration to say that she is the best-found and most comfortable vessel which has ever left our shores on a voyage of discovery.

The German Expedition has been more boldly planned than ours. It is new and experimental all through, as befits a young nation in its first exuberant efforts in a new field. If some people suppose that it may have made mistakes that our expedition has avoided; these at least are new mistakes from which new lessons are to be learned. If risks must be run-and we of the twentieth century are, I trust, no more timid of incurring risks than our predecessors of the nineteenth, or 
the eighteenth, or even the seventeenth-it is good that they should be new risks. To scientific men in Germany it appears natural and reasonable that a man of science should be the head of a scientific expedition; and that a geographer should lead a geographical expedition. Many British men of science sympathise in this view. Dr. Erich von Drygalski, one of the professors of geography in the University of Berlin, has been intrusted with the command to which he was appointed before the ship was designed, and for five years he has given all his time and thought to the expedition. He is supported by a band of highly trained specialists, who have spared neither time nor travel in mastering the subjects with which they may deal, and each has also received a general training in the subjects of all his colleagues - an admirable precaution. The captain of the Gauss, who belongs to the Merchant Service, has taken a course of training from the Norwegian whalers off Spitzbergen. He will, of course, be absolute master of the ship and crew in all that concerns order and safety, but he will be under the direction of the leader in all that concerns the plan of the voyage and the execution of scientific work. This arrangement is one which has always seemed to me to be desirable, that the captain of a ship on scientific service should occupy a position in relation to the scientific chief similar to that of the captain of a yacht in relation to the owner; but it is subject to the drawback that a naval officer could not well be asked to accept such a divided command.

But whatever our views as to ideal organisation may be, we are all certain that both expeditions will do the utmost that they can to justify the confidence that is placed in them and to bring honour to their flags. We know that the officers and staff of the Discovery belong to a race which, whether trained in the university or in the navy, has acquired the habit of bringing back splendid results from any quest that is undertaken.

A Definition of Geography-The bright prospects of Antarctic exploration must not, however, blind us to the fact that exploration is not geography, nor is the reading or even the writing of text-books, nor is the making of maps, despite the recognition of leading cartographers as "Geographers to the King." These are amongst the departments of geography, but the whole is greater than its parts.

The view of the scope and content of geography which I have arrived at as the result of much work and some little. reading during twenty years is substantially that held by most modern geographers. But it is right to point out that the mode of expressing it may not be accepted without amendment by any of the recognised leaders of the science, and for my own part I believe that discussion rather than acceptance is the best fate that can befall any attempt at stating scientific truth.

Put in the fewest words, my opinion is that

Geograpiy is the science which deals with the forms of relief of the Earth's crust, and with the infuence which these forms exercise on the distribution of all other phenomena.

This definition looks to the form and composition of the Eurth's crust itself, and to the successive coverings, partial and complete, in which the stony globe is wrapped. We sometimes hear of the New Geography, 
but I think it is more profitable to consider the present position of Geography as the outcome of the thought and labours of an unbroken chain of workers, continuously modified by the growth of knowledge, yet old in aim, old even in the expression of many of the ideas that we are apt to consider the most modern.

Some Historical Landmarks. - Claudius Ptolemæus, about 150 A.D., gathered into his great Geography the whole outcome of the Greek study of the habitable world. He laid stress on the threefold nature of descriptions of the Earth's surface: the general sketch of the great features of the world alone receiving the name of Geography, the more special description of an area he termed Chorography, and the detailed account of a particular place Topography.

Aristotle, who first adduced real proofs of the sphericity of the Earth, had not failed to note the relationships which exist between plants and animals, and the places in which they are found, and he argued that the character of peoples was influenced by the land in which they lived; but Ptolemy cared little for theories, comparisons, or relationships, confining himself rather to the record of actual facts. He made errors, the results of which were more important, as it happened, in advancing knowledge than were the truths which he recorded; for after the troubled mediæval sleep, when even the spherical form of the Earth was blotted out of the knowledge of Christendom, the scientific deductions made by Toscanelli from the false premises of Ptolemy heartened Columbus for his westward voyage to the Indies, on the very outset of which he stumbled all unknowing on the New World. When Magellan succeeded in the enterprise which Columbus had commenced, the fourteen centuries' reign of Ptolemy in geography came to an end; his work was done.

The rapid unveiling of the Earth in the sixteenth and seventeenth centuries cast a glamour over feats of exploration which has not yot been wholly dissipated, and it may not be easy, even now, to obtain wide credence for the fact that the explorer is usually but the collector of raw material for the geographer.

It is of vital interest to trace the re-formation of the theory of geography after its interruption in the Middle Ages. The fragments of the old Greek lore were cemented together by new and plastic thoughts: crudely enough by Apian, Gemma Frisius, and Sebastian Munster in the sixteenth century, but with increasing strength and completeness by Cluverius, Carpenter, and Varenius in the seventeenth.

The First Oxford Geographer.-The names of Cluverius and Varenius are familiar to every historian of geography; but that of Carpenter, I am afraid, is now brought to the notice of many geographical students for the first time. He was not so great as Varenius; but he was the first British geographer to write on theoretical geography as distinguished from mathematical treatises on navigation or the repetition of narratives of travel, and I think that there is evidence to show that his work had an influence on his great Dutch contemporary. 
Nathaniel Carpenter, Fellow of Exeter College, Oxford, published his book in 1625 under the title-

"Geographie delineated forth in two Bookes. Containing the Sphericall and Topicall parts thereof," and with the motto from Ecclesiastes on its title-page-

"One generation commeth, and another goeth, but the Earth remayneth for ever."

The great merits of Carpenter's treatise are his firm grasp of the relation of one part of geography to another, his skilful blending of the solid part of the work of Aristotle and Ptolemy with that of the explorers and investigators of his own generation, and the wholesome common-sense that dominates his reasoning. His definition is comprehensive and precise :

"Geographie is a science which teacheth the description of the whole Earth. The Nature of Geographie is well expressed in the name: For Geographie resolved according to the Greeke Etymologie signifieth as much as a description of the Earth; so that it differs from Cosmographie, as a part from the whole. Forasmuch as Cosmographie according to the name is a description of the whole world, comprehending under it as well Geographie as Astronomie. Howbeit, I confesse, that amongst the ancient Writers, Cosmographie has been taken for one and the self-same science with Geographie as may appeare by sundry treatises meerely Geographicall, yet intituled by the name of Cosmographie."

The differences held by Ptolemy to distinguish geography from chorography Carpenter shows to be merely accidental, not essential, and as to geography he says "It is properly tearmed a Science, because it proposeth to it selfe no other end but knowledge; whereas those faculties are commonly tearmed Arts, which are not contented with a bare knowledge or speculation, but are directed to some farther work or action. But here a doubt seems to arise, whether this Science be to be esteemed Physicall or Mathematicall? Wee answer, that in a Science two things are to bee considered : first, the matter or object whereabout it is conversant; secondly, the manner of handling and explication: For the former no doubt can bee made but that the object in Geographie is for the most part Physicall consisting of the parts whereof the Spheare is composed; but for the manner of Explication it is not pure but mixt; as in the former part Mathematicall, in the second rather Historicall; whence the whole Science may be alike tearmed both Mathematicall \& Historicall; not in respect of the subject which we have said to be Physicall but in the manner of Explication."

Although somewhat diffuse in expression, the meaning of these statements is clear and sound, and to the British public as new now as it was in the days of King Charles. The book treats of mathematical geography and cartography, of magnetism, climates, the nature of places, of hydrography, including the sea, rivers, lakes and fountains, of mountains, valleys and woods, of islands and continents, and at considerable length of people and the way in which they are influenced by the land in which they. live. Whether Dr. Carpenter lectured on geography in Oxford I do not know, but his book must have acquired a 
certain ourrency, for a second edition appeared in 1635, and it seems probable that it was known to Varenius.

Varenius and Newton.-Varenius, a young man who died at twentyeight, produced in Latin a single small volume published in 1650 , which is a model of conciseness of expression and logical arrangement well worthy even now of literal translation into English. So highly was it thought of at the time that Sir Isaac Newton brought out an annotated Latin edition at Cambridge in 1672.1 The opening definition as rendered in the English translation of 1733 (a work spoilt in most places by a parasitic growth of notes and interpolations) runs :-

"Geography is that part of mixed mathematics which explains the state of the Earth and of its parts, depending on quantity, viz. its figure, place, magnitude, and motion with the celestial appearances, etc. By some it is taken in too limited a sense, for a bare description of the several countries; and by others too extensively, who along with such a description would have their political constitution."

Varenius produced a framework of Physical Geography capable of including new facts of discovery as they arose; and it is no wonder that his work, although but a part, ruled unchallenged as the standard textbook of pure geography for more than a century. He laid stress on the causes and effects of phenomena as well as the mere fact of their occurrence, and he clearly recognised the vast importance upon different distributions of the vertical relief of the land. He did not treat of human relations in geography, but, under protest, gave a scheme for discussing them as a concession to popular demands.

Kant.-As Isaac Newton, the mathematician, had turned his attention to geography at Cambridge in the earlier part of the eighteenth century, so Immanuel Kant, the philosopher, lectured on the same subject at Königsberg in the later part. The fame of Kant as a metaphysician has defrauded him of much of the honour that is his due as a man of science. As Professor Hastie puts it: "His earlier scientific work, like an inner planet merged in light, was thus almost entirely lost sight of in the blaze of his later philosophical splendour."

Kant, it will be remembered, considered that the communication of experience from one person to another fell into two categories, the historical and the geographical: that is to say, descriptions in order of time or in order of space. The science of geography he considered to be fundamentally physical, but physical geography formed the introduction and key to all other possible geographies, of which he enumerated five: mathematical, concerned with the form, size, and movements of the Earth and its place in the solar system; moral, taking account of the customs and characters of mankind according to their physical surroundings; political, concerning

I Dugdale, in the introduction to the English translation published in 1733, states explicitly that Newton produced his version for the benefit of the students attending his lectures "on the same subject" from the Lucasian chair; but we have been unable to find any more satisfactory evidence that Newton actually lectured on Geography at Cambridge. 
the divisions of the land into the territories of organised governments; mercantile, or, as we now call it, commercial geography; and theological, which took account of the distribution of religions. It is not so much the cleavage of geography into five branches, all springing from physical geography like the fingers from a hand, which is worthy of remark, but rather the recognition of the interaction of the conditions of physical geography with all other geographical conditions. The scheme of geography thus acquired an unity and a flexibility which it had not previously attained, but Kant's views have never received wide recognition. If his geographical lectures have been translated, no English or French edition has come under my notice; and such currency as they obtained in Germany was checked by the more concrete and brilliant work of Humboldt, and the teleological system elaborated in overwhelming detail by Ritter.

The teleological views of Ritter were substantially those of Paley. The world, he found, fitted its inhabitants so well that it was obviously made for them down to the minutest detail. The theory was one peculiarly acceptable in the early decades of the nineteenth century, and it had the immensely important result of leading men to view the Earth as a great unit with all its parts co-ordinated to one end. It gave a philosophical, we may even say a theological, character to the study of geography.

Kant's views had pointed to such an unity, but from another side, that of evolution. It was not until after Charles Darwin had fully restored the doctrine of evolution to modern thought that it was forced upon thinking men that the fitness of the Earth to its inhabitants might result not from its being made for them, but from their having been shaped by it. It is certain that the influence of the terrestrial environment upon the life of a people has been carried too far by some writersby Buckle, in his History of Civilisation, for example-but it is no less certain that this influence is a potent one.

The Nature of Geography. - Granted that such influence is exercised, some objectors may urge that geography has nothing to. do with the matter; and we are compelled to acknowledge that the meaning and contents of geography are in this - country as variously interpreted as the colour of the chameleon in the traveller's tale. Yet my thesis is that it is just this relation between the forms of the solid crust of the Earth and all the other phenomena of the surface that constitutes the very essence of geography.

It is a fact that many branches of the study of the Earth's surface which were included in the cosmography of the sixteenth century, the physiography of Linnæus, the physical geography. of Humboldt, and perhaps even the Erdkunde of Ritter, have been elaborated by specialists into studies which, for their full comprehension, require the whole attention of the student. Geology, meteorology, oceanography, and anthropology, for example, have been successively specialised out of geography; but it does not follow that these specialisations fully occupy the place of geography, for that place is to co-ordinate and correlate all 
the special facts concerned so that they may throw light on the plan and the processes of the Earth and its inhabitants. Geography, in fact, is concerned with the results, not with the processes of the special sciences; and the limits between geography and geology, to take a single instance, are to be drawn, not between any one class of phenomena and another, but between one way and another of marshalling and utilising the same facts. This was clear to Carpenter in 1625 , though we have almost forgotten both it and him.

The Principles of Geography.-The principles of geography-the "pleasant principles," to use the phrase of old William Cuningham in 1559 - on which its claims to status as a science rest are generally agreed upon by modern geographers, though with such variations as arise from differences of standpoint and of mental process. The evolutionary idea is unifying geography as it has unified biology, and the whole complicated subject may be presented as the result of continuous progressive change brought about and guided by the influence of external conditions. These views have been expressed often in recent years, but they do not seem to have been very seriously considered, and no excuse need be offered for presenting them once more, though in an epitome curt to baldness.

The science of geography is of course based on the mathematical properties of a rotating sphere; but if we define geography as the exact and organised knowledge of the distribution of phenomena on the surface of the Earth, we see the force of Kant's classification, which subordinated mathematical to physical geography. The vertical relief of the Earth's crust shows us the grand and fundamental contrast between the oceanic hollow and the continental ridges; and the hydrosphere is so guided by gravitation as to fill the hollow and rise upon the slopes of the ridges to a height depending on its volume, thus introducing the great superficial separation into land and sea. The movements of the water of the ocean are guided in every particular by the relief of the sea-bed and the configuration of the coast lines. . Even. the distribution of the atmosphere over the Earth's surface is affected by the relief of the crust, the direction and force of the winds being largely dominated by the form of the land over which they blow. The different physical constitution of land, water, and air, especially the great difference between the specific heat and conductivity or diathermancy of the three, causes changes in the distribution of the sun's heat; and as a result the simple.climatic zones and rhythmic seasons of the mathematical sphere are distorted out of all their primitive simplicity. The whole irregular distribution of rainfall and aridity, of permanent, seasonal, and variable winds, of seaclimate and land climate, is the resultant of the guiding action of land forms on the air and water currents, disturbed in this way from their primitive theoretical circulation. So far we see the surface forms of the Earth, themselves largely the result of the action of climatic forces, and constantly undergoing change in a definite direction, controlling the two great systems of fluid circulation. These in turn control the distribution of plants and animals, in conjunction with the direct action of surface 
relief, the natural regions and climatic belts dictating the distribution of living creatures. A more complicated state of things is found when the combined physical and biological environment is studied in its incidence on the distribution of the human race, the areas of human settlement, and the lines of human communications. The complication arises partly from the fact that each of the successive earlier environments acts both independently and collectively; but the difficulty is in greater degree due to the circumstance that man alone among animals is capable of reacting on his environment and deliberately modifying the conditions which control him.

It seems to me that the glory of geography as a science, the fascination of geography as $a$ study, and the value of geography in practical affairs, are all due to the recognition of this unifying influence of surface relief in controlling, though in the higher developments rather by sugges. tion than dictation, the incidence of every mobile distribution on the Earth's surface.

The Classification of Geography.-Following out this idea, we are led to a classification of the field of geography in a natural order, in which every department arises out of the preceding with no absolute line of demarcation, and merges into the succeeding in the same way. This classification, it is necessary to note, is not like a series of pigeon-holes, which may be placed in any arbitrary order, but like a chain, in which the succession of the links is essential and unalterable.

Since form and dimension are the first and fundamental concepts in geography, the first and basal division is the Mathematical. Mathematical geography leaves the Earth as a spinning ball lighted and warmed according to a rigid succession of diurnal and annual changes. This merges into the domain of Physical Geography, which involves the results of contemporary change in the crust and the circulation of the fluid envelopes, with the resulting modifications in the simple and predictable mathematical distributions. This division falls naturally into three parts: Geomorphology, dealing with the forms of the solid crust and the changes they are undergoing at the present time; Oceanography, dealing with the great masses of water in the world; and Climatology, dealing with the effects of solar energy in the air. But all three spheres -lithosphere, hydrosphere, and atmosphere-are so closely inter-related that no one of them can be studied without some preliminary knowledge of the others. This forms the largest and most important part of geography, more varied and intricate than the mathematical, better known, and more definite than those involving life.

Bio-geography, the geographical distribution of life, arises directly from physical geography, which dominates it, but it is full of complex questions which involve the biological nature of the organism and the influence of physical environment, in which geographical elements, although predominant, do not act alone. Difficult as some of the problems of the distribution of life are at the present day, the remains of living creatures found fossil in the rocks, and the survivors of archaic forms still lingering in remote islands, supply us with our only instru- 
ment of research into the geography of past ages, often making it possible to lay down the areas of land and water in earlier geological periods.

The relation of man to the surface of the Earth detaches itself from the rest of Bio-geography by the number of exceptions to general laws of distribution and by the human power of modifying environment. It has necessarily been formed into a special department, Anthropo-geography. In primitive man the control exercised by environment is nearly as complete and simple as in the case of the lower animals; but with every advance in culture fresh complications are introduced. The relation of people to the land they inhabit, the choice of sites for dwellings and towns, the planning and carrying into effect of lines of communication, are all obviously much under the control of land form and climate. - When people get settled in a favourable position they usually become attached to it; they acquire, one may say, the colour of the land, in modes of thought as well as in manner of life. The poems of Ossian and the Crofter Question require for their elucidation a knowledge of the geographical conditions of the Western Highlands, just as the Border ballads and the Border raids were largely conditioned by the geography of the Southern Uplands.

Attachment to the native valley or the native fields leads to the holding of lands by clans or tribes and the fusion of tribes into nations, while changes in physical conditions stimulating migration from a deteriorating country may lead to the invasion of settled territories by homeless hordes. Here Anthropo-geography buds off the subdivision of Political Geography, which takes account of the artificial boundaries separating or subdividing countries, and of the innumerable artificial restrictions and ameliorations which are superimposed on the natural barriers and channels of intercommunication. Even in political geography only a humble place is held by a statement of boundaries and capitals, to lists of which the great name of Geography has actually been confined by people who ought to have known better.

Anthropo-geography views the world from the standpoint of the race, political geography from the standpoint of the nation; but room has to be found for a yet more restricted outlook, that of the individual, whose view of the world as it profits himself is known as commercial geography. This department deals with natural commodities and their interchange, and perhaps because here rather than in the other departments a successful comprehension of the inter-relation of cause and effect may be, in the language of the schoolroom, "reduced to pounds, shillings, and pence," the name of Applied Geography has been proposed. It fitly terminates our survey of the science, for the flickering disturbances of the equilibrium of supply and demand known simultaneously over the whole world, and the slower movements of transport to restore equilibrium, are still far from the power of scientific prevision, and all we can do at present is to point out certain clear lines of least resistance, or greatest advantage, due to the interactions of natural and human causes and effects.

To sum up in a sentence the field and the function of geography in 
the broad majesty of its completeness, we may say that it is the description of the surface of the solid Earth as it is in itself, as it acts upon the ocean, the air, and the living things which inhabit it, and as it is affected in turn by their actions.

Geography and the State.-Viewed thus, I believe that geography will be found to afford an important clue to the solution of every problem affecting the mutual relations of land and people, enlightening the course of history, anticipating the trend of political movements, indicating the direction of sound industrial and commercial development.

It would be possible, unfortunately it would be easy, to enumerate misconceptions of history, blunders in boundary settlements, errors in foreign policy, useless and wasteful wars, mistakes in legislation, failures in commercial enterprise, lost opportunities in every sphere, which are due to the neglect of such a theoretical geography. Surely it is to the laws defining the interaction of Nature and Man that we should turn for guidance in such affairs, rather than to the dull old British doctrine of "muddling through." That vaunted process after all means that we are driven by stress of facts to do without intending it, or knowing how, and at immense expense, the very things that intelligent study beforehand would have shown to be necessary, feasible, and cheap.

All this has been urged again and again, and it has fallen on the ears of those in authority "like a tale of little meaning though the words are strong." I admit that all advocates of a rational geography have not escaped the danger of the special pleader-they have promised too much. If a government official were to say : "Yes, I confess there was a mistake here, the affair was managed badly, much money and some prestige were lost: it must all be done over again; please tell me how"; I am afraid that the chances are that the answer would be vague, general and unpractical. If the answer to this boldly hypothetical question is ever to be clear and definite, geography must be studied as it has never yet been studied in this country. It must pass beyond the stage of a pastime for retired officers, colonial officials, and persons of leisure, and become the object of intense whole-hearted and original study by men of no less ability who are willing to devote, not their leisure, but their whole time to the work. The object of geographical research should be nothing less than the demonstration or refutation of what we claim to be the central principle of geography - that the forms of terrestrial relief control all mobile distributions.

A Projected Geographical Description.-In order to focus the question it may be convenient to consider the geography-or chorography, as Ptolemy would have termed it-of the British Islands. . No author has ever attempted to give such a description. Camden's Britannia was swamped by archxology; the county histories, which are certainly not deficient in number, were wrecked outward bound on the harbour-bar of genealogy. Sir John Sinclair's old Statistical Account of Scotland in the intelligent utilisation of very incomplete data. was a great but solitary stride in the right direction. Bartholomew's great. Atlas of Scotland supplies the cartographical basis for a modern description of the northern 
kingdom; but the description itself has not been undertaken on an equal scale. The work of producing a complete geographical description of the British Islands would be gigantic, but not hopelessly difficult.

The material has been collected at an enormous expenditure of public money, and is stacked more or less accessibly, much of it wellseasoned, some I fear spoilt by keeping; but there it lies in overwhelming abundance, heaps of building materials, but requiring the labour of the builder before it can become a building.

There is first and chief the. Ordnance Survey, one of the grandest pieces of work in mathematical geography that has ever been accomplished. The result is a series of maps almost as perfect as one can expect any human work to be, showing in a variety of scales from $\frac{1}{4}$ of an inch to 25 inches to a mile every feature of the configuration of the land-except the lake-beds.

There is next the hydrographic survey by the Admiralty, giving every detail of the subaqueous configuration in and around our islandsexcept the lake-beds.

These two great surveys supply the basis for a complete description of the British Islands, and the geological survey, which in a sense is more elaborate than either of the others, completes the fundamental part. The geological map makes it possible to explain many of the forms of the land by referring to the structure of the rocks which compose them. Both the geological and hydrographic surveys are accompanied by memoirs describing the features, and discussing the various questions arising from the character of each sheet; but there is nothing of the kind for the maps of the ordnance survey.

The ordnance maps show at the date of their preparation the extent and also the nature of the woodlands and moorlands, and this information is supplemented by the Returns of the Board of Agriculture, which each year contain the statistics of farm crops, waste land, and livestock for every county. These returns are excellently edited from the statistical point of view, but they are not discussed geographically. It is easy to see in any year how much wheat is raised in each county, but it is a slow and laborious process to discover from the Returns what are the chief wheat-growing areas of the country. The county is too large a unit for geographical study, as it usually includes many types of land form and of geological formation. Before the distribution of crops can be understood or compared with the features of the ground they must be broken up into parishes, or even smaller units, and the results placed on maps and generalised. The vast labour of collecting and printing the data is undertaken by Government, and paid for by the people without a murmur, but the geographer is left in ignorance for the want of a comparatively cheap and simple cartographic representation of the facts.

The Inspectors of Mines and the Board of Trade publish statistics of the industry and the commerce of the country, statistically excellent, no doubt, but in most cases lacking the cartographic expression which makes it possible to take in the general state of the country from year to year. The same is true of the Registrar-General's Returns of births, marriages, and deaths, in themselves an admirable epitome of the health 
conditions of the country, and of the fluctuations in population, but limited by a narrow specialism to the one purpose.

Finally and chiefly we have the Census Reports. Once in ten years the people are numbered and described by sex, age, and occupation. The inhabited houses are numbered, and the smaller dwellings grouped according to size. The figures are most elaborately classified and discussed, so as to bring out the distribution of population, and its change from the previous decade. But to the geographer the Census Reports are like a cornfield to a seeker of bread. The grains must be gathered, prepared, and elaborated before the desired result is obtained. Nowhere is the cartographic method more useful than here. It is a striking contrast to turn to the splendid volumes of the United States Census Reports, many of them statistically inferior to ours, but thickly illustrated with maps, showing at a glance the distribution of every condition which is dealt with, and enabling one to follow decade by decade the progressive development of the country, and to study for each census the relations between the various conditions.

These are only a few of the statistical publications, produced by Government, and embodying year after year a mass of conscientious labour, which, save for a few specialists who extract and utilise what concerns themselves, is annually "cast as rubbish to the void."

One small department supported by public money, but under unofficial direction, may be referred to as an example of the successful employment of cartographic methods. - This is the Meteorological Council, appointed by the Royal Society, and charged with the collection of meteorological data and the publication of weather reports, forecasts, and storm warnings. The maps published twice daily to show the distribution of atmospheric pressure and temperature are only rough sketches and very much generalised, yet they serve the purpose of presenting the facts in a graphic form, yielding at a glance information which could only be extracted from tables by long and laborious efforts. The pilot charts, published monthly by the same department, showing the average conditions of air and sea over the whole North Atlantic, and the occasional atlases of oceanographical data, are valuable geographical material.

The official work of Government is supplemented by the voluntary labours of many societies, in whose transactions much valuable material is stored, and in not a few cases is admirably discussed. But even with these supplements gaps remain which must be filled by private enterprise before a complete geographical description can be compiled.

Considering the Ordnance Survey alone it is hardly credible and not at all creditable that the Treasury should veto the extension of the survey to the lake-beds on the score of expense, yet such is the fact. The directors of the Survey have shown themselves ready to encourage private workers by placing the data presented by them upon the maps with due acknowledgment.

The Survey of the Lakes. - It is with profound satisfaction that I now make an aunouncement-by special favour the first public announcement - of a scheme of geographical research on a national scale by private 
enterprise. Sir John Murray and Mr. Laurence Pullar have resolved to complete the bathymetrical survey of all the fresh-water lakes of the British Islands. Mr. Laurence Pullar will take an active part in the proposed survey, and has made over to trustees a sum of money sufficient to enable the investigation to be commenced forthwith and to be carried through in a comprehensive and thorough manner. It is intended to make the finished work an appropriate and worthy memorial of $\mathrm{Mr}$. Pullar's son, the late. Mr. Fred Pullar, who had entered enthusiastically upon the survey of the lochs of Scotland, and whose heroic death while endeavouring to save life in Airthrey Loch last February must be present to the memory of many of you. Large sums of money devoted in good faith to scientific purposes do not always bring about the wished-for result; but in this case there is no room for anxiety on that score. Sir John Murray, with whom Mr. Fred Pullar had worked for several years, has generously promised to direct the whole scheme, and to be responsible for carrying it out. All the lakes of the British Islands will be sounded and mapped as a preliminary to the complete limnological investigation which is proposed. The nature of the deposits, the chemical composition of the water and its dissolved gases, the rainfall of the drainage areas, the volumes of the inflowing and outflowing streams, the fluctuations in the level of the surface, the seasonal changes of temperature, and the nature and distribution of aquatic plants and animals, will all receive attention. The geological history of the lakes may also be inquired into with reference to such points as the growth of deltas, the erosion of the margins, and, perhaps, the conditions of the old dead lakes that are now level meadows.

Five years at least will be required to make these observations and to incorporate them in memoirs, each of which will be a complete natural history of the lakes of one river basin. The proposed work wants more than money, direction, and time. It requires the services of several young and enthusiastic workers-preferably men who have completed their University course and are anxious to devote some time to research. Sir John Murray and Mr. Pullar wish to meet three or four capable young fellows, one preferably a chemist, one a geologist, one a botanist, and one a zoologist. When found they will be offered a salary sufficient to enable them to give their whole time to the work, but not large enough to induce any one who has not the love of science at heart to take it up. From my experience when working in somewhat similar conditions at the Scottish Marine Station seventeen years ago, I can promise those who will have the good fortune to be selected plenty of hard work for which they will get the fullest credit-and this they will appreciate more keenly when they come to know the world better-and I can promise them also in their association with Sir John Murray a course of scientific and intellectual training such as even the universities do not afford.

Other Desirable Surveys. - The Geological Map requires to be supplemented by additional work on the nature of the superficial soil as it affects agriculture, such as is expressed in the Cartes agronomiques of France, going more fully into the chemical nature of the soil than is 
possible on the Drift Maps of the Survey which so usefully supplement the maps of solid geology. Such experiments as have been made at the College at Reading in collecting analyses of the soils in the neighbourhood might very well be carried out at the agricultural colleges and other centres all over the country. It would form an invaluable supplement to the work of the Government geologists.

Of equal value, though, perhaps, more obviously so to the scientific than to the "practical" man, is the study of the natural vegetation of the country. In a highly cultivated land like ours there are comparatively few places where the native flora remains in possession; but the mapping of the main crops which have supplanted it is nearly as useful. To become satisfactory from this point of view, the statistics of the Board of Agriculture ought to be supplemented by surveys made by trained botanists on the ground. A valuable beginning has been made under the ever-fertile stimulus of Professor Patrick Geddes in the two sheets of a map of the plant-associations of Scotland compiled by the late Robert Smith, whose premature death last year was a loss to science. It would be a splendid thing if this map could be finished as a memorial to the brilliant young botanist in the same way as the survey of the lakes is proposed as a memorial worthy of Fred Pullar, and I am glad to learn that there is some probability of it being carried on.

Of all the other distributions which might be worked out cartographically time fails us to speak; but reference must be made, however briefly, to a few.

Geography of the Air:-With regard to Meteorology, the distribution of temperature and pressure over the British Islands for the year and for the separate months have been worked out by the experienced hand of Dr. Buchan, and published both in separate memoirs and in the Meteorological Atlas, edited by Dr. Buchan and Dr. Herbertson. But such observations as the degree of cloud or of sunshine can as yet be treated only in a superficial and generalised way for want of data. Perhaps the most important and certainly the most difficult of all the atmospheric conditions to discuss fully is precipitation. It depends on so many varying conditions, such as the form and exposure of the land, the altitude above sea-level, the direction and force of the wind, the relative frequency of thunderstorms, the distance from the sea, the direction of the average paths of cyclonic storms, etc., that far more numerous and more long-continued observations are required to establish the normal condition of the country than in the case of either temperature or pressure. When we reflect that the whole water-supply of the country depends directly on rainfall, and when we remember that the value of water-power made available by differences of level promises to be greater in the future than it has been in the past, we can see that a study of rainfall in conjunction with configuration' may prove as valuable for the localisation of the manufacturing centres of the future as the geological survey was for those of the present.

Thanks to the remarkable foresight and the untiring exertions of the late Mr. Symons, the volunteer rainfall observers of this country have 
been encouraged to organise their efforts, and by working on a common plan have accumulated within the last forty years a mass of observations unrivalled for number and completeness in any other land. But as yet. the difficulties in the way of constructing a map of normal rainfall on an adequate scale have not been overcome, and much experimental work will probably be necessary before it can be accomplished. To this task it is my ambition to devote myself. I may be permitted to state that Scotland is far behind England or Wales in the number of rainfall stations per square mile. Thus there is, roughly, one rain-observing station for every 20 square miles of England, one for every 30 square miles of Wales, but only one for every 67 square miles of Scotland, and one for every 170 square miles of Ireland.

Rainfall observations only tell the amount of available water; the configuration of the stream-beds must be considered in determining water-power. The only country I know where the horse-power of the rivers has been measured and mapped is Finland, but of course individual rivers, such as the Mississippi, Rhine, Seine, and Thames, have been thoroughly studied. Before many decades have passed it will be a necessary element in the surveys of all countries, though at present the available data are few and scattered.

Population Maps.-In considering human geography we come to the most interesting and least occupied field of research. Until Mr. Bosse constructed his beautiful maps of the density of population of Scotland and England we had absolutely no cartographical representation of the true distribution of people over the land. To map population by counties gives a very poor idea of the truth, for in such counties as Yorkshire or Perthshire there are large areas entirely without inhabitants, and small areas where the population is very dense. Mr. Bosse's maps were made on the principle of leaving blank all the land on which there were no dwelling-houses, and so obtaining a close approximation to the true density of population of the inhabited area. For Scotland his map shows at once that it is a function of configuration. It shows the densely peopled lowland plain, the less densely peopled coast-strip surrounding the country, and the less densely peopled valleys running inland into the great uninhabited areas. The population map of England, on the other hand, shows an absolutely startling relation to the geological structure, which in turn is closely related to the configuration. We are not astonished to see the centres of densest population coinciding with the Coal Measures, but it is both surprising and instructive to see how the density of population runs parallel to the strike of the Secondary and Tertiary rocks of south-eastern England, a band of the lightest population following each outcrop of chalk and limestone, a band of dense population following each belt of sandstone or clay.

Anthropo-geography teems with fascinating subjects of research. The admirable investigations in the West of Ireland on the physical anthropology of the people might well be extended to the whole country outside the great towns, where all evidence of place of origin and original character is speedily lost. Good work has been done in this way by the

voL. XVII. 
Ethnographic Survey promoted by a committee of this Association, and a committee of the Royal Scottish Geographical Society has rendered great aid to the Ordnance Survey in the cognate study of the place-names of Scotland.

The distribution of religion, even in the three typical forms of Anglican, Presbyterian, and Roman Catholic-forms so typical as to be, broadly speaking, national-is most imperfectly known. The objection to a religious census is one which is somewhat difficult of comprehension in Scotland, and too polemic for sober discussion in England. But a few of the problems are worth being worked out by individuals. The curious islands of Roman Catholic continuity in Lancashire, the Hebrides, and the Highlands can probably be related simply enough to the configuration of the country and the means of communication as influencing free movement of people at critical periods of history. There are many interesting points as to the geographical distribution of surnames, the relation of characteristic literature or poetry to specific areas, things small in themselves, but capable of exercising very far-reaching influence if systematically worked out.

Geographical Synthesis.-Granted that the subsidiary surveys have been made and the results put in a strictly comparable form, the central problem remains - the synthesis of the complete geography of the country. This can perhaps be solved best by comparing the maps of the various distributions in the proper order, and seeing how far they are related to one another. For the general discussion the Ordnance Map on the scale of 1 inch to a mile should be used, and each natural region ought properly to be treated by itself, but as a matter of practical convenience it would probably be found best to select either the artificial boundaries of counties or the still more arbitrary lines bounding sheets of the map. Whatever small area is taken as the unit of description, it should be treated in such a way as to seek for and prove or disprove the existence of any control exercised by the form of the land and its geological character on the outcrops of the rocks, the nature of the soil, the course of the rivers, the temperature and movements of the air, the rainfall, the vegetation and agriculture, the distribution of population, the sites of towns, villages, and isolated dwellings, the roads, railways, and harbours, the birth-rate and death-rate, and on the progressive changes in all these conditions which are shown in the discussion of the statistics collected annually or decennially. When such unit areas are worked out individually the results can easily be combined and condensed into a geographical description that will be complete, well balanced, and symmetrical. The work is practicable ; it only requires time, money, direction, and workers to carry it out; but although a specimen memoir, prepared by the authority of the Royal Geographical Society, met with a certain measure of approval, all attempts failed to obtain funds for making the work complete, and the scheme must await a more educated generation before it can be profitably revived in its entirety. But meanwhile this field for geographical study and research lies at the doors of every university where the subject is or may be recognised, and the labours of professors and 
students might be profitably directed to the completion of such memoirs for the surrounding district, gradually working farther and farther afield. The idea is no more new than every other "thing under the sun." Such exercises, not so elaborately planned, but the same in essentials, were ordinary subjects for theses in the universities of Sweden and Finland during the eighteenth century. To come nearer home, the local handbooks prepared for successive meetings of the British Association are frequently very fair examples of the geographical description of a district. The essential qualities are rarer in guidebooks, but we must not forget one brilliant exception, the poet Wordsworth's Guide to the English Lakes.

It is pleasant to hear that through the encouragement of Sir John Murray the Scottish Natural History Society is taking up the systematic study of the basin of the Forth, and they will, I feel sure, give a good account of their labours. One point which must be very strongly emphasised is that a geographical treatise is distinguished from a jumble of facts mainly by the order and proportion in which the phenomena are dealt with, and by the relation of cause and effect that is established between them.

As to the utility of complete geographical descriptions, we must of course recognise their greater practical importance in new and developing countries than in old lands like our own. Yet even with us the study of the distribution of natural resources may suggest important changes, involving great redistributions of population.

A Geographical Warning.-Hitherto, except as regards exploration and cartography, the position of geography in this country has never been satisfactory. Times are changing, and even in exploration we are now only one amongst many rivals, often better equipped by education, usually in no way deficient in daring. Although the best work of several of our cartographers in Edinburgh and London need fear no comparison, we cannot conceal the fact that Germany leads the world in map-making. As regards the recognition or even the comprehension of geography by the State, by the universities, and by the public, we are equally far behind our neighbours across the North Sea.

It has sometimes been hinted that the study of geography has been deliberately discouraged by politicians or by merchants because too much knowledge on the part of the public might embarrass foreign policy or lead to mercantile competition; but we surely cannot entertain such unworthy suspicions. I am inclined to attribute the neglect of the subject merely to ignorance of its nature due to imperfect education.

Two cases in which the application of geography to political and practical affairs suggests a definite course of action may be mentioned as examples. There is still one important colonial boundary, entirely undelimited in a region somewhat difficult of access and still little known, where goldfields will probably be found or reported before long, and where a very serious international question may suddenly arise in a part of the world absolutely unsuspected by most people, even amongst those who interest themselves in general politics and in colonial affairs. It would cost a comparative trifle to survey the region in question, and to 
lay down that boundary line before the goldfields are touched, so that no international trouble could ever arise. What it may cost to postpone the matter until claims have been pegged out on debatable land, the British Guiana and Venezuela arbitration, the Alaska difficulty, and South Africa are there to tell us. It would be interesting to calculate, now that the cost of a week of fighting is known, the saving in pennies on the income-tax that would have accrued from a survey of South Africa if that had been carried out as an imperial duty when Cape Colony was settled. I do not for a moment suggest that a survey would have prevented the war; but it is not unreasonable to believe that it would have shortened it by some months. In this connection it is satisfactory to know that a valuable report has been drawn up by a Committee of the British Association, presided over by Sir Thomas Holdich, embodying a scheme for the systematic survey of British protectorates.

The second example comes nearer home. The utilisation of windand water-power must increase in importance as mineral fuel diminishes in amount or increases in price. Wind-and water-power will never fail as long as the sun shines and the land remains higher than the sea; but what may fail unless timely precautions are taken is the power of utilising them for the benefit of the community at large. Are the existing laws as to water-rights, and the absence of laws as to the utilisation of wind desirable and satisfactory? The usual answer to such questions is, "Why trouble about that just now? These matters are not urgent, other things are." That argument is answerable for many disasters. The inevitable is in many if not in most cases simply another name for the unforeseen. It is inevitable that the country will be impoverished if the utilisation of wind- and water-power and the transport of that power by electricity are not wisely safeguarded and provided for; but when a survey of our resources, the circulation of the air over our islands, and the effects produced by the interposition of the mountains, plateaus, and valleys upon it, plainly points to the possibility of such a trouble, it only becomes inevitable as a result of culpable negligence.

- These two examples, which will not strike any one whose mind is wholly occupied in paying the penalties of old neglect, illustrate my contention that a complete geographical description based on full investigation is of the highest and most urgent importance, not for this country only, but for the Empire, and for every country in the world.

Nor is it the land alone which claims attention. It is of the utmost. importance to investigate and evaluate the resources of the surrounding seas. The recent International Conference for the exploration of the sea held at Christiania formulated a scheme of research which has been taken up enthusiastically by Belgium, Holland, Germany, Denmark, Russia, Sweden, and Norway. Its object is to place the fisheries of Northern Europe on a scientific basis, and to make for that purpose a comprehensive survey of the sea, which will prove of high value to meteorology, and through it to agriculture as well. The recent work by Mr. H. N. Dickson on the circulation of the surface waters of the North Atlantic in conjunction with similar work by Professor Pettersson in Sweden shows how hopeful: 
such researches are from the purely scientific standpoint, and their practical importance is no less. It remains with our Government to show that this country is not indifferent to an opportunity, such as has never presented itself before, of placing one of our great national industries on a basis of scientific knowledge. This is in my belief one of the cases in which the expenditure of thousands now will mean the saving of millions a few years hence.

It is magnificent to send out Polar expeditions, and they speak volumes for the greatness of the human mind that can give itself to the advancement of knowledge for the sake of knowledge, knowing that it will bring no material gain; and I trust that such a spirit will continue to manifest itself until no spot of Earth, no land however cold or hot, no depth of sea, no farthest limit of the atmosphere remains unsearched and its lesson unlearnt. But I insist that the full study of our own country is on a-totally different footing. Magnificent it may be, too, but sternly practical, since it is absolutely essential for our future well-being, and even for the continuance of the nation as a Power amongst the states of the world. Still, there is every probability that such work will be neglected until the events which it should avert are upon us, and then it will be too late to make provisions which now could be done cheaply, easily, and effectively.

A Proposed Remedy. - The few attempts which have been made in this country to promote the study of geography or to diminish the discouragements to geographical research have had but slight success. Much has been done to improve geographical teaching by the Royal Geographical Society, the Royal Scottish Geographical Society, the Geographical Association, this Section of the British Association, and other bodies; but that is not my theme. I refer to the little that has been done towards the elaboration of a geographical theory and the elucidation of geographical processes. Amongst the not inconsiderable number of teachers of geography in the universities and colleges of Great Britain there is not one man who receives a salary on which he can live in decent comfort so as to devote all his time, or a substantial part of it, to geographical research ; and the same is true of every official of all the geographical societies. Not one is paid an income sufficient to enable him to devote the time not occupied by mechanical routine to any other purpose than supplementing his income by outside workwriting text-books, correcting examination papers, perhaps even practising journalism. If by an effort and the sacrifice of some of the comforts considered necessary by most people of the professional classes he devotes a few odd hours now and then to some original research, he finds very few to consider it seriously; some friendly expressions of opinion possibly, but scarcely a reader; and it counts for nothing, save, perhaps, in enhancing the reputation of his country in other lands where scientific work, no matter in what department, is valued in a due degree. All this must be changed before much progress can be made. No doubt a giant of genius would ignore all obstacles and pursue his work regardless of recognition; but such giants are not to be looked for many 
times in a century. It should be made possible for a man of fair abilities to receive as much opportunity, encouragement, recognition, and reward for good work in geography as for good work, let us say, in chemistry or electricity. That is all that can reasonably be asked, and that is what is freely accorded in other countries where the status of the man of science is higher than it is with us. It is here that help may be hoped for from the Scottish universities in the strength of their new endowments. If a Chair of Geography were instituted with the purpose of promoting research first and teaching afterwards, properly equipped with books, maps, and apparatus, and held on the understanding that no outside work was to be undertaken, something might yet be done to restore our country to the position it held a century and a half ago, when a text-book of geography was published without a thought of sarcasm, containing a frontispiece representing "Britannia instructing Europe, Asia, Africa, and America in the Science of Geography."

\section{ON THE CONGO: THE BELGIAN SCIENTIFIC EXPEDITION} TO KA-TANGA.

Communication made by Captain Charles LemaIre, of the 2nd Regiment of Belgian Artillery, head of the Expedition, to the Geographical Section of the British Association for the Advancement of the Sciences.

By inviting us to present a communication relating to the Belgian Scientific Expedition to Ka-Tanga, the Geographical Section of the British Association for the Advancement of Science has done us a great honour. This.honour we cannot accept for ourselves; we transfer it altogether to the work carried out in Africa by Belgium and by the King of the Belgians.

I say we cannot accept this honour for ourselves, for we know too well what we have done has been an easy thing to do, and one of such absorbing interest that the work itself has sufficiently rewarded our exertions. In giving all honour to the African work of King Leopold II., we have to regret that we were not more fully qualified to produce by our labours all that one is entitled to expect from explorers so fully equipped, and whose field of investigation was so entirely virgin soil that they could not fail to return with full hands.

I will with your permission give you a rapid summary of the objects of the Belgian Scientific Expedition to Ka-Tanga, so that you may be able to judge of the exact value of its results.

It would be out of place in this learned assembly to dwell on the part which the science should play in the direction of human activity; I will only say that any explorer who would pretend to scientific rank must relate all that he has observed without the least consideration of public or private affairs. He has been given not an object to be attained, 